\title{
Collaborative Efforts in Handling Foreigners Stranded in Indonesia During the Covid-19 Pandemic
}

\author{
Koesmoyo Ponco Aji ${ }^{1, *}$ Wilonotomo ${ }^{2}$ Trisapto Wahyudi Agung Nugroho ${ }^{3}$ \\ ${ }^{1}$ Undergraduate Program in Migration Studies at the Immigration Polytechnic, \\ ${ }^{2}$ Undergraduate Program in Immigration Technology Management at the Immigration Polytechnic \\ ${ }^{3}$ Research and Development Agency for Law and Human Rights \\ *Corresponding author. Email: ponco@poltekim.ac.id
}

\begin{abstract}
The Covid-19 pandemic has significantly changed the pattern of human movement globally. Resistance to this visible enemy has led many countries to close their gates to restrict human passage. The closure of borders, restrictions on the movement of people and goods by many countries seem unable to prevent the massive spread of the coronavirus in the world. On the other hand, closing borders certainly have a domino effect on the country, government and the region. One of the multiple consequences in the immigration sector that is greatly felt by this pandemic is the emergence of the phenomenon of foreigners stranded in a country, as experienced by Indonesia. This case does not only occur to those who travel irregularly but also to those who are regular travellers. It cannot be denied that the problem of stranded foreigners is not just a matter of immigration alone, but is much more complex. This phenomenon certainly has implications for the social and economic problems of a country. A collaborative approach is needed to deal with this phenomenon. This study aims to answer empirically one of the biggest challenges facing immigration agencies in the world during the Covid-19 pandemic regarding the handling of foreigners stranded in Indonesia. The theme chosen was the collaborative efforts needed to ensure freedom of movement and immigration during the Covid-19 pandemic. This will discuss the handling of the Covid-19 Pandemic in Indonesia. The research method used is in the form of descriptive analysis by examining data and information obtained from official government websites and other sources. The results of this study aim to provide an overview, explanation, and validation of the phenomena studied regarding the handling of stranded foreigners and official standard procedures related to the process of returning foreigners to their countries during the Covid19 pandemic conditions related to human traffic (migration) between countries. It was concluded that collaborative efforts were needed to ensure freedom of movement and immigration during the Covid-19 pandemic in Indonesia, particularly in dealing with the phenomenon of stranded foreigners.
\end{abstract}

Keywords: covid-19 pandemic, stranded foreigners, immigration, collaboration.

\section{INTRODUCTION}

The Covid-19 pandemic has changed the movement of people in the world. Human movements in this situation are forced to stop or very limited. This is because human movement is the main factor that causes the spread of Covid-19 in the world. For countries affected by the coronavirus, many of them are imposing a temporary closure of their country's borders (lockdown) of course on a scale set by each country. The change in human movement in the form of a global cessation of movement is unprecedented. The implication for human mobility is a change in human mobility patterns during the Covid-19 pandemic [1].

Since declared a pandemic by WHO on March 11, 2020, the spread of Covid-19 in the world and the region, even in Indonesia itself, does not seem to stop. Even though several regions in Indonesia have shown a positive trend of decreasing the spread and suffering, in some areas the trend is still high [2]. The same thing is experienced by countries in the world. Based on the data published by Johns Hopkins 
University on October 17, 2020, there have been more than 39 million cases of Covid-19 affecting 189 countries and/or sovereign territories [3].

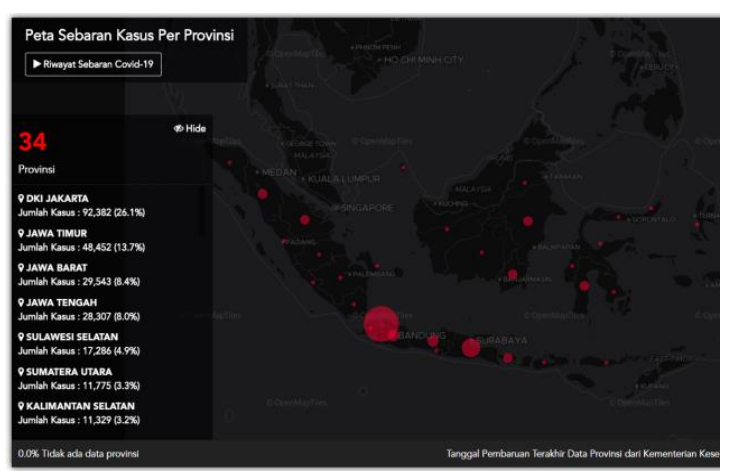

Figure 1 Graph of the development of the Covid19 case in Indonesia dated October 16, 2020

From an immigration perspective, of course, the Covid-19 pandemic has major implications, especially in border management and monitoring the presence and activities of foreigners within the country's territory. In brief, the challenges faced by immigration in Indonesia in particular and in the region in general during this pandemic are [4] :

(1) handling traffic of persons at the border;

(2) the risk of spreading the virus to officers;

(3) handling of foreigners stranded on the territory of the country; and

(4) internal and external communication in implementing emergency policies.

It cannot be denied that the problem of stranded foreigners is not just a matter of immigration alone, but is much more complex. The handling of stranded foreigners and official standard procedures related to the process of returning these foreigners to their country when the conditions of the Covid-19 pandemic must be found a solution. Referring to the foregoing, handling stranded foreigners in the territory of a country becomes homework that must be resolved immediately.

\section{RESEARCH METHOD}

The research method used is a descriptiveanalytical research method that provides an overview of the object under study based on the original data collected, without making any conclusions first [5]. In other words, analytical descriptive research focuses on the problems that occur when the research is carried out, then the results of the research are processed and analyzed to obtain conclusions. All data and information obtained from official government websites and other sources are collected to form a complete picture of the phenomenon to be studied. The data and information obtained are then processed qualitatively with descriptive-analytical methods to obtain an overview of the status of symptoms at the time of the study (expose de facto) or to see what conditions exist in the situation [6].

The empirical data obtained from this study are the results of observations, interview results, search results from government websites and other online media. The data and information obtained are used as material for analysis in research to be described in a scientific narrative so that it can answer research questions, namely the collaborative efforts made by immigration in dealing with foreigners stranded in Indonesia.

\section{FINDINGS AND DISCUSSION}

At the end of December 2019, the Chinese government reported a series of pneumonia cases infected with the Novel Coronavirus in the Wuhan area to the World Health Organization. Since it was first detected in humans, the Novel Coronavirus, which is better known as the coronavirus (Covid19 ), has spread rapidly throughout the world. It was recorded that until early February 2020 these cases had been found in 27 countries and regions [7]. Based on actual data held by WHO, until 16 October 2020, only 18 (eighteen) international legal entities (countries, territories, other sovereign areas) did not report any Corona-19 cases in their territories [8]. Based on the WHO dashboard related to the coronavirus and referring to the COVID-19 Dashboard by the Center for Systems Science and Engineering (CSSE) at Johns Hopkins University (JHU), until the $42^{\text {nd }}$ week since it was first announced the trend of the development of this case globally is still climbing as shown below.

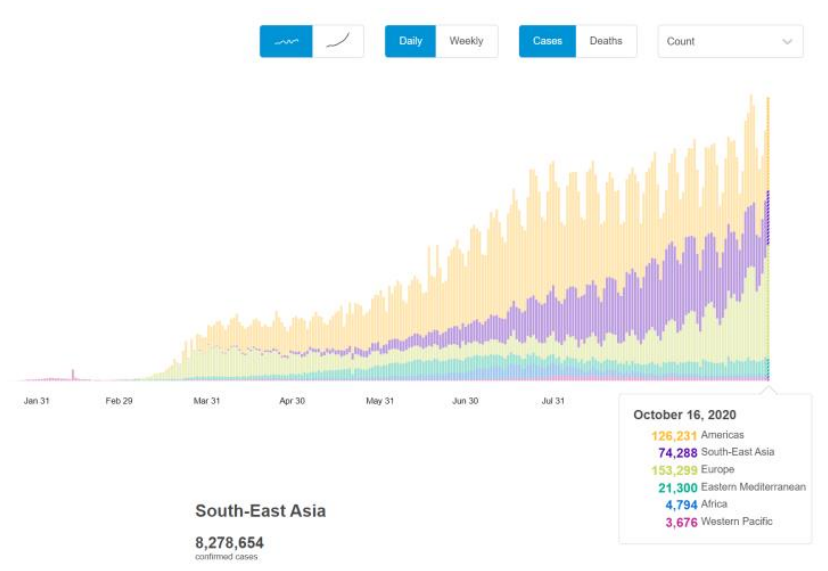

Figure 2 Graph of the development of Covid-19 cases in the world [9] 


\subsection{Closing of Gates to Restrict Human Passing}

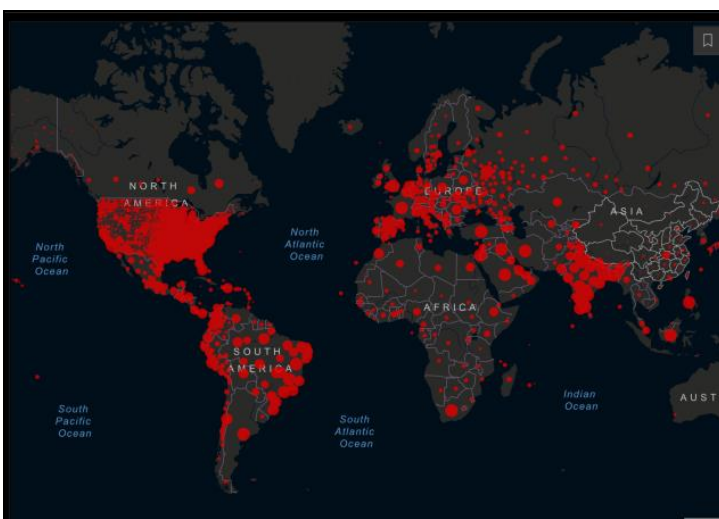

\begin{tabular}{|l|c|l|c|}
\hline \multicolumn{4}{|c|}{ Cases by Country/Region/Sovereignty } \\
\hline USA & 8.050 .147 & $\begin{array}{l}\text { South } \\
\text { Africa }\end{array}$ & $\begin{array}{c}700.20 \\
3\end{array}$ \\
\hline India & 7.432 .680 & UK & $\begin{array}{c}692.11 \\
2\end{array}$ \\
\hline Brazil & 5.200 .300 & Iran & $\begin{array}{c}522.38 \\
7\end{array}$ \\
\hline Russia & 1.376 .020 & Chile & $\begin{array}{c}488.19 \\
0\end{array}$ \\
\hline $\begin{array}{l}\text { Argenti } \\
\text { na }\end{array}$ & 965.609 & Iraq & $\begin{array}{c}420.30 \\
3\end{array}$ \\
\hline $\begin{array}{l}\text { Colomb } \\
\text { ia }\end{array}$ & 945.354 & Italy & 391.61 \\
\hline Spain & 936.560 & Bangladesh & $\begin{array}{c}386.08 \\
6\end{array}$ \\
\hline France & 876.342 & Germany & 359.80 \\
& & & 2 \\
\hline Peru & 859.740 & Indonesia & 357.76 \\
& & & 2 \\
\hline Mexico & 841.661 & Philippines & 354.33 \\
& & & 8 \\
\hline
\end{tabular}

Figure 3 Map of the distribution of Covid-19 cases and data on the top 20 Covid-19 cases in the world dated 17 October 2020 [3]

The massive spread of the coronavirus causes changes in human movement. Referring to the data above, the development of Covid-19 cases has increased again in 5 (five) European countries. This has resulted in locking borders and stopping migration back to occur in many countries. France has declared curfews in its main cities, including Paris, while Germany and Italy have ordered midnight closings for bars and restaurants. The UK has three levels of restriction depending on the regional prevalence of the virus [10]. Likewise in
Indonesia, after the implementation of the Transitional Large-Scale Social Restrictions (PSBB) since 5 June which was extended up to 5 (five) times until 10 September, on 14 September 2020 in the capital Jakarta, the PSBB Total was carried out again [11]. This is solely to reduce the potential for transmission of the coronavirus in the environment of Jakarta residents.

During the coronavirus pandemic, we can see the similarity of the code of behaviour carried out by countries in the world. Entering the $12^{\text {th }}$ week of the pandemic, the closure of borders is a code of behaviour that is carried out by relay in the regional to world scope. Many countries are increasingly closing borders. Badly stricken Italy preceded this policy and was followed by France, which imposed punishments on citizens who roam outside the residence for no good reason. Many European countries close land borders to prevent the entry of foreigners. Canada and the United States have closed their land borders. Brazil has closed its border with Venezuela [10]. To maintain security in the health sector, several countries immediately closed their crossing gates at the beginning of the pandemic period. However, some countries postpone the closure of their borders with strategic considerations of their country. Indonesia in the Southeast Asia region is the last country to close its borders.

\begin{tabular}{|c|c|l|}
\hline COUNTRY & $\begin{array}{c}\text { DATE OF } \\
\text { CLOSURES }\end{array}$ & EXPLANATION \\
\hline Malaysia & $\begin{array}{c}18 \text { March } \\
2020\end{array}$ & \\
\hline Myanmar & $\begin{array}{c}19 \text { March } \\
2020\end{array}$ & \\
\hline Timor Leste & $\begin{array}{c}19 \text { March } \\
2020\end{array}$ & \\
\hline Australia & $\begin{array}{c}20 \text { March } \\
2020\end{array}$ & \\
\hline Cambodia & $\begin{array}{c}21 \text { March } \\
2020\end{array}$ & \\
\hline Philippines & $\begin{array}{c}22 \text { March } \\
2020\end{array}$ & \\
\hline Vietnam & $\begin{array}{c}22 \text { March } \\
2020 *\end{array}$ & partial closures in \\
\hline Brunei & $\begin{array}{c}23 \text { March } \\
2020 *\end{array}$ & $\begin{array}{l}\text { Partial open int'l } \\
\text { flight }\end{array}$ \\
\hline Darussalam & 24 March & \\
\hline Singapore & 2020 & \\
\hline Thailand & $\begin{array}{c}26 \text { March } \\
2020\end{array}$ & \\
\hline
\end{tabular}




\begin{tabular}{|c|c|l|}
\hline Lao & $\begin{array}{c}01 \text { April } \\
2020\end{array}$ & \\
\hline \multirow{2}{*}{ Indonesia } & $\begin{array}{c}02 \text { April } \\
2020^{*}\end{array}$ & $\begin{array}{l}\text { partial closures } \\
\text { from January } \\
\text { until April }\end{array}$ \\
\hline
\end{tabular}

Table 1. Closure of national borders in Southeast Asia and Australia [12]

However, closing the border is not the main solution in preventing the spread of Covid-19. In fact all over the world, the number of exposure to Covid19 remains high even though the death rate due to Covid-19 tends to be stable and is starting to decline [9].

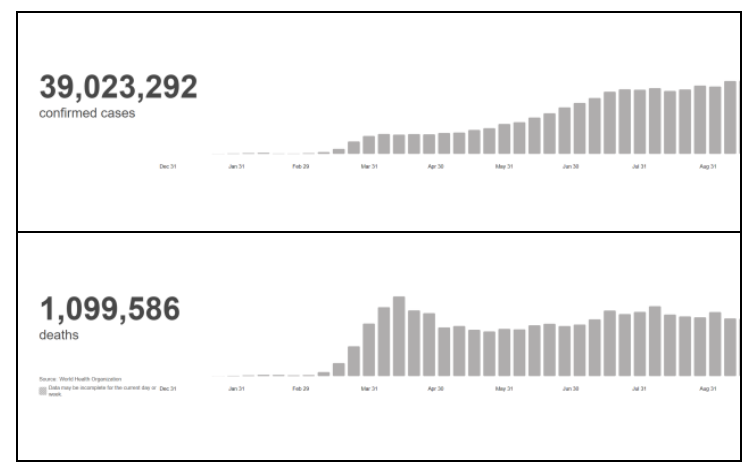

Figure 4 Graph of global exposure (top) and death (bottom) due to Covid-19 dated October 17,2020 [9]

\subsection{Border Closing Domino Effect}

Almost all countries are feeling the effects of this Corona-19 pandemic. Indonesia is one of the countries most affected by the Covid-19 crisis. Some experts and scholars consider the delay in closing the border, the lack of a centralized government response has made the handling of this pandemic seem uncoordinated [13]. On the other hand, the closure of this border has dealt a heavy blow to various sectors, particularly the supporting sectors of the economy, such as agriculture, plantations, tourism and transportation, also, the informal sector and foreign workers have felt a tremendous blow [14]. Referring to ASEAN data regarding economic growth and forecasts of economic development during the Covid-19 pandemic the gulf of economic recession in Indonesia and other ASEAN countries as a domino effect of border closure is approaching [15].

\begin{tabular}{|c|c|l|l|l|l|}
\hline Country & \multicolumn{2}{|c|}{ Initial Forecast } & \multicolumn{2}{c|}{ Revised Forecast } & Source \\
\hline $\begin{array}{c}\text { Brunei } \\
\text { Darussalam }\end{array}$ & $1.5 \%$ & $\begin{array}{l}\text { Sep } \\
2019\end{array}$ & $2.0 \%$ & $\begin{array}{l}3 \mathrm{Apr} \\
2020\end{array}$ & ADB \\
\hline Cambodia & $6.8 \%$ & $\begin{array}{l}\text { Sep } \\
2019\end{array}$ & $2.3 \%$ & $\begin{array}{l}3 \mathrm{Apr} \\
2020\end{array}$ & ADB \\
\hline
\end{tabular}

\begin{tabular}{|c|c|c|c|c|c|}
\hline \multirow{2}{*}{ Indonesia } & \multirow{2}{*}{$5.3 \%$} & \multirow{2}{*}{$\begin{array}{l}\text { Aug } \\
2019 \\
\text { Official } \\
\text { target }\end{array}$} & $\begin{array}{l}4.7 \% \text { to } \\
5.0 \%\end{array}$ & $\begin{array}{l}4 \text { Mar } \\
2020\end{array}$ & \multirow{2}{*}{$\begin{array}{l}\text { Ministry of } \\
\text { Finance }\end{array}$} \\
\hline & & & $\begin{array}{c}-0.4 \% \text { to } \\
2.3 \%\end{array}$ & $\begin{array}{l}1 \text { Apr } \\
2020\end{array}$ & \\
\hline Lao PDR & $6.2 \%$ & $\begin{array}{l}\text { Sep } \\
2019\end{array}$ & $3.5 \%$ & $\begin{array}{l}3 \mathrm{Apr} \\
2020\end{array}$ & $\mathrm{ADB}$ \\
\hline \multirow{2}{*}{ Malaysia } & \multirow{2}{*}{$4.8 \%$} & \multirow{2}{*}{$\begin{array}{l}\text { Official } \\
\text { target }\end{array}$} & $\begin{array}{c}3.2 \% \text { to } \\
4.2 \% \\
\end{array}$ & $\begin{array}{l}\text { Feb } \\
2020 \\
\end{array}$ & \multirow{2}{*}{$\begin{array}{l}\text { Ministry of } \\
\text { Finance, } \\
\text { Bank Negara } \\
\text { Malaysia }\end{array}$} \\
\hline & & & $\begin{array}{c}-2.0 \% \text { to } \\
0.5 \%\end{array}$ & $\begin{array}{l}3 \text { Apr } \\
2020\end{array}$ & \\
\hline Myanmar & $6.8 \%$ & $\begin{array}{l}\text { Sep } \\
2019\end{array}$ & $4.2 \%$ & $\begin{array}{l}3 \text { Apr } \\
2020\end{array}$ & $\mathrm{ADB}$ \\
\hline \multirow[b]{2}{*}{ Philippines } & \multirow[b]{2}{*}{$\begin{array}{l}6.5 \% \\
\text { to } \\
7.5 \%\end{array}$} & \multirow[b]{2}{*}{$\begin{array}{l}\text { Official } \\
\text { target }\end{array}$} & $\begin{array}{c}5.5 \% \text { to } \\
6.5 \%\end{array}$ & $\begin{array}{l}\text { Mar } \\
2020\end{array}$ & \multirow[b]{2}{*}{ NEDA } \\
\hline & & & $\begin{array}{c}-0.6 \% \text { to } \\
4.3 \% \\
\text { (If the } \\
\text { outbreak } \\
\text { lasts } \\
\text { until } \\
\text { June) }\end{array}$ & $\begin{array}{l}19 \\
\text { Mar } \\
2020\end{array}$ & \\
\hline \multirow{2}{*}{ Singapore } & \multirow{2}{*}{$\begin{array}{l}0.5 \% \\
\text { to } \\
2.5 \%\end{array}$} & \multirow{2}{*}{$\begin{array}{l}\text { Nov } \\
2019\end{array}$} & $\begin{array}{c}-0.5 \% \text { to } \\
1.5 \%\end{array}$ & $\begin{array}{l}17 \\
\text { Feb } \\
2020\end{array}$ & \multirow{2}{*}{$\begin{array}{l}\text { Ministry of } \\
\text { Trade and } \\
\text { Industry }\end{array}$} \\
\hline & & & $\begin{array}{c}-4 \% \text { to }- \\
1 \%\end{array}$ & $\begin{array}{l}26 \\
\text { Mar } \\
2020\end{array}$ & \\
\hline Thailand & $\begin{array}{l}2.7 \% \\
\text { to } \\
3.7 \%\end{array}$ & $\begin{array}{l}\text { Nov } \\
2019\end{array}$ & $\begin{array}{c}1.5 \% \text { to } \\
2.5 \%\end{array}$ & $\begin{array}{l}17 \\
\text { Feb } \\
2020\end{array}$ & $\begin{array}{l}\text { National } \\
\text { Economic } \\
\text { and Social } \\
\text { Development } \\
\text { Board }\end{array}$ \\
\hline \multirow[b]{2}{*}{ Vietnam } & \multirow[b]{2}{*}{$6.8 \%$} & & $\begin{array}{l}6.09 \% \\
\text { to } 6.2 \%\end{array}$ & $\begin{array}{l}5 \mathrm{Feb} \\
2020\end{array}$ & \multirow{2}{*}{$\begin{array}{l}\text { Ministry of } \\
\text { Planning and } \\
\text { Investment }\end{array}$} \\
\hline & & & $5.96 \%$ & $\begin{array}{l}13 \\
\text { Feb } \\
2020\end{array}$ & \\
\hline $\begin{array}{l}\text { *note: Brun } \\
\text { anticipation } \\
\text { refineries st } \\
2020)\end{array}$ & grow & 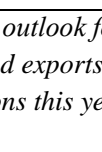 & 2020 has & en revi & $\begin{array}{l}\text { d upwards in } \\
\text { new } \\
\text { Outlook }\end{array}$ \\
\hline
\end{tabular}

Table 2. ASEAN Member State (AMS) Gross

Domestic Product (GDP) growth forecasts for 2020 [15]

Although it is predictive, the analysis carried out in April 2020 appears to have started to occur in the ASEAN region with statements from several highranking state officials regarding the recession experienced by their respective countries [16]. In addition to the economy, of course, border closure has a direct effect on immigration as one of the main task and function holders at the border as well as services and supervision of foreigners. Since the enactment of Regulation of the Minister of Law and Human Rights of the Republic of Indonesia Number 11 of 2020 concerning the Temporary Prohibition of Foreigners from Entering the Territory of the Republic of Indonesia on March 31, 2020, the 
Government of the Republic of Indonesia has officially prohibited foreign nationals (WNA) from entering or transiting Indonesian territory as of since April 2, 2020. This provision was then followed by implementing regulations below, including Circular of the Director General of Immigration Number IMIGR.01.01-2325 of 2020 dated April 2, 2020, concerning the Temporary Prohibition of Foreigners Entering the Territory of the Republic of Indonesia, and Circular of the Director General of Immigration Number IMI-GR.01.01-2493 of 2020 dated May 8, 2020, concerning Procedures for Granting Entry Permits for ITAS / ITAP / IMK / Visa Approval / Visa that have expired [17]. In addition to changing immigration policies regarding the crossing of foreigners, closing borders globally creates new problems, namely the emergence of the phenomenon of stranded foreigners.

\subsection{The Stranded Stranger}

\subsubsection{Definitions and Concepts}

Until the end of 2019, the phenomenon of stranded foreigners tended to be associated with refugees and asylum seekers. This phenomenon can generally be seen in many refugee pockets in the border areas of European countries [18]. Also, cases of boat people that occur in Europe, Southeast Asia and Australia are often categorized as stranded foreigners. Although it does not rule out the phenomenon of stranded foreigners, it also includes cases of fishermen who are stranded in foreign countries and cases of tourists who have lost their travel documents and living expenses in the middle of nowhere in the country they are visiting. However, this is not a major concern of the world because it is casuistic and in minor numbers [18].

In terms of terminology, there is no generally accepted definition of the term stranded stranger. This term has no legal status and remains somewhat descriptive, with some scholars describing it as a description of the situation, not the status of a person. Concerning stranded foreigners, some scholars claim that there is no inherent right to them so there is no need for a full definition [19]. According to Vincent Chetail, professor of international law and director of the Center for Global Migration, the term stranded foreigner can apply to almost any group of refugees, with the only thing in common being that they cannot get out of the situation they are in [19]. The earliest reference to stranded migrants is found in a 1981 review of a book about illegal aliens who made it into the Middle West countryside on the United States border from Mexico but remained isolated there and unable or unwilling to proceed onto American soil or back to Mexico [20]. It was not until the 1990s that the term stranded foreigner was actively used in the context of the collapse of the Soviet Union when many people turned out to be living in a 'foreign' country without a clear legal status [21].

In recent years, the term "stranded foreigner" has been used in particular by IOM with the voluntary return assistance program and the Stranded Migrant Facility (SMF). In 2007, IOM published a chapter entitled The Legal Protection of Stranded Migrants, which is considered the first publication to specifically address this phenomenon. The focus is on foreigners who find themselves legally displaced because they cannot legally reside in the country where they are physically present, or move to another country, or return to their home country [22]. UNHCR has also changed its understanding of the term "stranded foreigner". In 1994, UNHCR identified persons stranded as refugees who had been prevented from entering the country of their choice and who did not wish to return to their home country [23]. Two decades later, in 2010, UNHCR again defines "stranded foreigners" as people who do not need international protection and who cannot legally reside on the territory of the host country, move legally to another country, or return to their home country [23].

\subsubsection{Reason for Stranding: Border Politics and Other Things}

The inability of people to migrate can be caused for a variety of reasons. However, experts agree that in common cases it is due to border politics for special reasons and strict controls that restrict human movement [20]. In common cases, the increasingly stringent border controls imposed by countries of destination often lead to the diversion of migration routes which are then exploited by smugglers, resulting in high-cost crossings. Also, the lack of documentation caused by the migrants themselves or being removed by other parties is the reason for the failure of migration [18]. And finally, the lack of financial resources means that migrants cannot continue their journey and are stranded in a certain area. However, during the Covid-19 pandemic, it is necessary to reformulate the reasons for someone being stranded in a foreign country. The approach to the concept of refugees and asylum seekers as the reason for the strandings of foreigners is not entirely appropriate given the difference in situations and conditions.

During the Covid-19 pandemic, tightening up to the closure of borders is a very tough political choice but must be implemented. As previously stated, Indonesia is the last country in the Southeast Asia 
region to close its borders to foreigners who are public crossers. The concept adopted by Indonesia is not the total closure of its country's borders, but rather the tightening of borders as stipulated in ministerial level regulations [24]. The Covid-19 pandemic not only brings public health problems but also has very broad economic implications. Through his tweet on April 2, 2020, President Joko Widodo said that every government policy in tackling this pandemic in the country always takes into account the economic life of the people [25]. Therefore the public must understand why Indonesia holds the final key in the general restrictions on foreign passers in their country. On the other hand, the tightening of borders by Indonesia and almost all countries in the world has caused many foreigners residing in that country to become detained in that country. This is what gave birth to a new version of the stranded stranger phenomena.

Then the second is about documentation. In this Covid-19 pandemic situation, the problem of documentation is not the main cause of the birth of the phenomenon of stranded foreigners. Those who are stranded in this case are generally legal passers or what is commonly referred to as regular migrants. The new problem is related to the legality of their immigration documentation. Of course, every foreigner who is in another country must have a residence permit. In the situation in Indonesia, provisions related to the obligation to have a residence permit for foreigners residing in Indonesian territory are directly regulated in the immigration law [26]. During the Covid-19 pandemic, the Indonesian government has issued emergency regulations that allow foreigners to obtain emergency residency permits as long as they cannot return to their home countries [27]. Formal legal policies do not necessarily eliminate the presence of stranded foreigners in Indonesia. This is only the legalization of the immigration documents that they are obliged to have but empirically does not eliminate their status as stranded foreigners.

The last one is related to the lack of financial resources. The first and last causes are two sides of the coin in giving birth to the status of stranded foreigners. Global border closings caused many world airlines to stop operating. Also, restrictions on repatriated people by some countries result in long queues for people to return to their home countries [28]. In Indonesia, before the border tightening to the border tightening period, 7,198 foreigners evacuated either individually or in groups [29].

\begin{tabular}{|c|c|}
\hline Location & Total Evacuated \\
\hline $\begin{array}{c}\text { Ngurah Rai Int'l Airport } \\
\text { (Bali) }\end{array}$ & 6.331 \\
\hline $\begin{array}{c}\text { Soekarno Hatta Int'l } \\
\text { Airport (Jakarta) }\end{array}$ & 867 \\
\hline Total & 7.198 \\
\hline
\end{tabular}

Table 3. Recapitulation of the Evacuation of Foreign Nationals in March-May 2020 Period [29]

With the tightness of human traffic globally and coupled with the lack of operating world airlines, human traffic during the Covid-19 pandemic has become a high cost. For those who use regular airlines, they have to wait for the certainty of the schedule and route to their destination. Both transportation costs and waiting periods are difficult to ascertain, of course, require a lot of financial resources. As for those who want to use an irregular flight, of course, it costs more. Here it can be seen that the lack of financial resources can be a strong reason for the creation of the stranger strand phenomenon.

\subsubsection{Examples of Cases of Stranded Foreigners in Indonesia}

The number of stranded foreigners in Indonesia is not very significant. This is due to the difficulty of tracking down the whereabouts of strangers experiencing the situation. When viewed statistically, no data can be used as a definite indicator in determining the stranded foreigner in Indonesia. Based on data from the Directorate General of Immigration, in April 2020 when the border tightening policy came into effect, 2,641 foreigners entered Indonesia using the Visit VisaFree facility and 2 foreigners entered Indonesia using the Visa on Arrival facility [30]. Then based on the same source, there were 52,864 issuances of Visiting Stay Permits (including Forced Stay Permits) in Indonesia [30]. From these data, it cannot be determined with certainty the number of stranded foreigners in Indonesia due to the limitations of the measuring variables.

However, empirically, an example of cases of stranded foreigners in Indonesia originating from legal (regular migrant) passers, one of which is the case of a Russian family in Mataram, Lombok. A family of Russian citizenship consisting of a male and female adult and a baby was found abandoned and homeless in Lombok. Their existence is cause for concern because they lack financial resources so they have to busk in one of the traditional markets in Lombok [31]. Another example that involved groups of people was the stranding of 45 tourists in the Mentawai islands due to the Covid-19 pandemic 
[32]. The two examples above illustrate that the phenomenon of stranded foreigners occurs in Indonesia.

Apart from cases of stranded foreigners in Indonesia who came from legal passers (regular migrants), there are also cases of stranded foreigners in Indonesia who came from illegal passers (irregular migrants). The most obvious example is the case of rescuing 94 Rohingya refugees who were adrift in North Aceh waters in June 2020 [33]. Then on 7 September 2020, 297 Rohingya refugees were stranded in Lhokseumawe, Aceh [34]. From the perspective of state sovereignty and international refugee law, Indonesia has no obligation to handle cases of stranded foreigners who are irregular migrants of this kind. Indonesia's generosity in accepting and handling them is based on humanity as stated in the fifth principle of the Indonesian nation's ideology, Pancasila. This case of irregular migrants makes the phenomenon of stranded foreigners transformed into a unique case and difficult to solve.

\subsection{Challenges of Handling Stranded Foreigners in Indonesia}

Following the facts above and looking at the development of immigration policies in the world, handling stranded foreigners in a country is a complicated matter. To provide an unlimited emergency stay permit policy is certainly not an easy thing for Indonesia. Travel restrictions, closure of immigration services, and limited financial resources are certainly challenges that foreigners then face. From the two perspectives above, the challenges related to stranded foreigners require a multidimensional approach. It will need a legal approach related to the regulation of his existence, a health approach related to his personal and environmental conditions and of course a humanitarian approach related to how to survive and return to his home country.

The current condition of being stranded is, of course, not like what Tom Hanks told in the film Cast Away, but it is much more complex. In the case of Indonesia, the government certainly does not ignore the presence of foreigners in Indonesia. But in the conditions of the Covid-19 pandemic, the safety of citizens is, of course, a priority. Of course, this condition cannot be handled by immigration alone. To respond to this, Indonesian immigration acts more in terms of regulations, namely by granting a Forced Stay Permit and exemption from overstaying foreigners stranded in Indonesia [27]. In the humanitarian aspect, such as accommodation and the necessities of daily living, handling is of course adjusted to conditions in the field. As on the island of Mentawai, accommodation for stranded foreigners is facilitated by the local government and resort owners until conditions allow them to return to their respective countries [35]. Whereas the handling of Rohingya refugees in Aceh is, of course, different, with their status as refugees, humanitarian guarantees are facilitated by the local government with the assistance of community social organizations and IOM [36].

In minimizing the phenomenon of stranded foreigners in Indonesia, the government through the Directorate General of Immigration has made a policy by granting a Forced Stay Permit (ITKT). This has essentially become an effective solution in answering the big question regarding the fate of foreigners' residence permits in Indonesia. The policy provided by the government is a solution that must be obeyed and understood carefully by both foreigners and parties related to the existence and activities of the said foreigner. This is a temporary answer to conditions of global border tightening so that foreigners do not have access to return to their home countries [37].

Apart from the efforts made internally, handling stranded foreigners must be pursued externally. A collaborative effort is required in addressing this problem, collaborative efforts are of course national and international. In terms of handling stranded foreigners in the country, the best collaborative effort is to involve all elements of the state. The government element as the leading sector must be able and willing to handle this problem. Elements of government in the fields of security, defence and law enforcement such as immigration, police, armed forces, maritime security agencies and other task forces such as local governments, social ministries and ministries of health must be at the forefront of handling this problem. On the other hand, community participation is also urgently needed in conducting early detection and handling of stranded foreigners in Indonesia.

Given that the problem of stranded foreigners is closely related to a person's citizenship status and nationality, international collaborative efforts are also imperative. From the several examples of stranded foreigners above, the participation of the international community will determine the success of the handling of these cases. The role of representatives of foreign countries represented through foreign representative offices/embassies in Indonesia is very helpful in accelerating the handling of stranded foreigners in Indonesia. The duties and functions of protecting citizens who are carried out 
by the foreign representative office/embassy provide quick access in providing accommodation and transportation for cases of Russian families in Mataram, Lombok. Likewise, the handling of cases of stranded foreigners who have the status of irregular migrants. The collaborative efforts carried out by the Indonesian government together with related international organizations accelerated the data collection process and the handling of these stranded foreigners. It is therefore important to consider how to better manage international cooperation in the world and to continue to be in deep contact with each other [38].

In connection with the phenomenon of stranded strangers, the following steps can be taken:

(1) There is an institution that acts as the leading sector;

(2) Immigration must have data related to the number and presence of foreigners in the territory of the country;

(3) The government, both central and regional, must be able to provide emergency shelter for isolation and preparation for returning to the country of origin

(4) There must be cross-country cooperation in the management of the return concerned

(5) Of course, to facilitate handling, the government must be willing to adopt the handling of the presence of stranded foreigners and the mechanism for returning them from other countries that have implemented it.

\section{CONCLUSION}

The coronavirus pandemic (Covid-19) is an international disaster. This virus attacks indiscriminately on anyone. There are various ways that humans and state entities can handle and prevent transmission. As an entity that has sovereignty over the territory, almost all countries have tightened and even closed their borders to prevent the spread of the coronavirus. Of course, the tightening and closing of the country's gates create a domino effect, both domestically, regionally and internationally. Not only affects the economic sector, but the domino effect is also felt in the immigration sector. The emergence of the phenomenon of stranded foreigners is one of the consequences of closing the country's gates. Responding to this phenomenon, the government cannot remain silent, 3 main things must be done, namely:

(1) making emergency regulations based on humanity;

(2) provide minimal life support for stranded foreigners so that they can return to their country, of course, according to the government's ability; and
(3) establish good international collaboration, both between countries and with related international organizations, in cooperation to respect humanity.

Of course, this can not only be applied during the coronavirus pandemic but can also be applied in any emergency on an international scale. Quoting what was conveyed by Fiona Andrew from the Australian Department of Home Affairs which stated, "is a very varied period for all of us, what this pandemic shows is we really are in this together, what is the way each country has responded may be slightly different, we all together fighting the same enemy, for once", for that we agree with the statement of H.E. Retno Marsudi (Minister of Foreign Affairs of the Republic of Indonesia) when being the keynote speaker at the Sustainable Preparedness for Health Security and Resilience meeting, Wednesday, October 1, 2020 which was held online "no country is able to solve this crisis alone. In this regard, we have no other choice but to rely on WHO as a platform for cooperation between countries. This crisis has become a momentum to review the global health management system so that it can better handle future outbreaks. In addition, there is a need for multisectoral and comprehensive cooperation in dealing with a pandemic. In this case, a whole-ofsociety approach can be the key to fighting the pandemic, not only at the national level but at the global level" [39].

In addition, in the context of realizing global collaborative efforts, there needs to be a joint protocol or procedure regarding the process of returning residents to their country of origin by complying with various health procedures during the COVID-19 pandemic conditions related to human traffic between countries.

\section{REFERENCES}

[1] H. Romdiati, "COVID-19 MENGUBAH POLA MOBILITAS PENDUDUK," Jakarta, 2020. [Online]. Available: https://kependudukan.lipi.go.id/id/berita/53 -mencatatcovid19/893-covid-19-mengubahpola-mobilitas-penduduk.

[2] C.-19 Handling Task Force, "Peta Sebaran," 2020. https://covid19.go.id/petasebaran (accessed Oct. 17, 2020).

[3] C. for S. S. and E. (CSSE) Johns Hopkins University (JHU), "An interactive webbased dashboard to track COVID-19 in real-time," 2020.

https://www.arcgis.com/apps/opsdashboard /index.html\#/bda7594740fd40299423467b4 
8e9ecf6 (accessed Oct. 17, 2020).

[4] B. Upskill, "Snapshot Report - Immigration Challenges During COVID-19," Melbourne, 2020. [Online]. Available: https://www.facebook.com/photo?fbid=101 $57535638225003 \&$ set $=$ pcb. 1783772501775 121.

[5] Sugiyono, Metode Penelitian Kuantitatif, Kualitatif dan R\&D. Bandung: Alfabeta, 2009.

[6] W. Surakhmad, Pengantar Penelitian Ilmiah Dasar, Metode, Teknik. Bandung: Transito, 1982.

[7] N. Haider et al., "Passengers' destinations from China: Low risk of Novel Coronavirus (2019-nCoV) transmission into Africa and South America," Epidemiol. Infect., vol. 363, no. February, 2020, doi: 10.1017/S0950268820000424.

[8] WHO, "Table of Covid19 International," 2020. https://covid19.who.int/table (accessed Oct. 17, 2020).

[9] WHO, “Covid19," 2020. https://covid19.who.int/ (accessed Oct. 17, 2020).

[10] P. Richardson, "Weekly Update: Global Coronavirus Impact and Implications," Counterpoint, 2020.

https://www.counterpointresearch.com/coro navirus-weekly-update/ (accessed Oct. 17, 2020).

[11] D. E. Nugraheny, "Landaikan Kasus Covid19, PSBB DKI Jakarta Diharap Tak Segera Dilonggarkan," Kompas.com, Jakarta, Sep. 28, 2020 .

[12] "Compiled from various sources," wikipedia, RMIT, Pikiran Rakyat, Kompas, 2020.

https://su.wikipedia.org/wiki/Fédérasi_Maé nbal_ASEAN (accessed Oct. 17, 2020).

[13] M. Walden and F. Ibrahim, "Pakar Epidemiologi di Australia Sebut Indonesia Terlambat Tutup Perbatasan Untuk Tangani Virus Corona," ABC News, Sydney, Apr. 02, 2020.

[14] B. Dekker, "The impact of COVID-19 measures on Indonesian value chains," CRU Policy Br., no. June, pp. 0-10, 2020.

[15] Association of Southeast Asian Nations (ASEAN), "Economic Impact of Covid-19 Outbreak on ASEAN," Assoc. Southeast
Asian Nations, vol. 1, no. April, pp. 1-17, 2020, [Online]. Available:

https://asean.org/storage/2020/04/ASEANPolicy-Brief-April-2020_FINAL.pdf.

[16] R. Sebayang, "Dari Singapura ke Malaysia, RI Dikepung Negara-negara Resesi," CNBC Indonesia, Jakarta, 2020.

[17] D. G. Immigration, "Informasi peraturan keimigrasian selama masa Pandemi Covid19," DGI, 2020.

https://www.imigrasi.go.id/covid19 (accessed Oct. 18, 2020).

[18] A. Theses and I. Lazarova, "Stranded Migrants in Macedonia," 2016, [Online]. Available: https://doi.org/20.500.11825/255.

[19] V. Chetail, "Stranded Migrants: Giving Structure to a Multifaced Notion," Glob. Migr. Res. Pap., 2013.

[20] R. Dowd, “Trapped in Transit: The Plight and Human Rights of Stranded Migrants," Geneva, 2008.

[21] IOM, Constitution of The International Organization For Migration. Venice, 1951.

[22] S. Grant, "The Legal Protection of Stranded Migrants," in International Migration Law: Developing Paradigms and Key Challenges, R. Cholewinski, R. Perruchoud, and E. MacDonald, Eds. Geneva: T.M.C. ASSER PRESS, 2007, p. 155.

[23] W. R. Böhning, Aid in Place of Migration?: Selected Contributions to an ILO-UNHCR Meeting, Illustrate. Geneva: International Labour Organization, 1994.

[24] Indonesia, Regulation of the Minister of Law and Human Rights of the Republic of Indonesia Number 11 of 2020 concerning the Temporary Prohibition of Foreigners from Entering the Territory of the Republic of Indonesia. Indonesia, 2020.

[25] J. Widodo, “Tweeter@jokowi," tweeter, 2020. https://twitter.com/jokowi (accessed Apr. 02, 2020).

[26] Indonesia, Act of the Republic of Indonesia Number 6 Year 2011 concerning Immigration. Indonesia, 2011.

[27] Indonesia, Regulation of the Minister of Law and Human Rights of the Republic of Indonesia Number 8 Year 2020 concerning Temporary Cessation of Free Visit Visas 
and Visit Visas on Arrival and Granting Forced Stay Permits. Indonesia, 2020.

[28] F. Diah, "Turis Australia Terjebak di Kanada, Anjingnya Bisa Pulang Duluan," detikTravel, Jakarta, Oct. 18, 2020.

[29] C. Koswala, "Peran Direktorat Jenderal Imigrasi dalam Pencegahan Penyebaran Covid-19," 2020.

[30] Directorate General of Immigration, "Statistical data of crossings of foreigners per country with the type of 30 days BVK and VKSK visa in 2020," Jakarta, 2020.

[31] T. Dirhantoro, "Kisah Keluarga Asal Rusia Terjebak di Lombok Imbas Covid-19, Mengamen Demi Bertahan Hidup," Kompas TV, Lombok, Apr. 30, 2020.

[32] W. Saputra and A. Lukmono, "Gara-gara Corona, 45 Turis Asing Terjebak di Pulau Mentawai," GATRAcom, Padang, Apr. 11, 2020.

[33] "Selamatkan Pengungsi Rohingya yang Dilarang Aparat untuk Mendarat, Al Jazeera Puji Warga Aceh 'Best of Humanity,"' Geloranews, Banda Aceh, Jun. 01, 2020.

[34] A. Jamil, "Lagi, Ratusan Pengungsi Rohingya Terdampar di Aceh," iNews, Banda Aceh, Sep. 07, 2020.

[35] Y. Aisyah, "Dampak Pandemi Corona, Turis Asing Tertahan di Mentawai," Kompas, Padang, Apr. 11, 2020.

[36] Rachmawati, "Rohingya di Aceh, Dilema Antara Kemanusiaan dan Potensi," Kompas, Banda Aceh, Jun. 30, 2020.

[37] B. H. Putra, "Pengaruh Pandemi Covid-19 Terhadap Kebijakan Keimigrasian Indonesia," Jakarta, 2020. [Online]. Available: http://www.politik.lipi.go.id/kolom/kolom2/politik-nasional/1412-pengaruh-pandemicovid-19-terhadap-kebijakan-keimigrasianindonesia.

[38] M. Hatuel-Radoshitzky and A. Heistein, "Global Governance and COVID-19: Why International Cooperation Still Matters," Challenges Glob. Gov. Amid COVID-19 Pandemic, pp. 10-12, 2020, [Online]. Available: https://www.inss.org.il/wpcontent/uploads/2020/05/Globalgovernance-and-COVID-19-Whyinternational-cooperation-still-matters---
An-article-by-Michael-Hatuel-Radoshitzkyand-Ari-Heistein-in-A-Council-on-ForeignRelations-paper.pdf.

[39] Ministry of Foreign Affairs of the Republic of Indonesia, "Menlu RI: COVID-19 momentum dunia perkuat sistem kesehatan global hadapi pandemi di masa depan," Ministry of Foreign Affairs, 2020. https://kemlu.go.id/portal/id/read/1752/berit a/menlu-ri-covid-19-momentum-duniaperkuat-sistem-kesehatan-global-hadapipandemi-di-masa-depan (accessed Oct. 18, 2020). 